\title{
FLIGHT PHENOLOGY OF VESPID WASPS (HYMENOPTERA, VESPIDAE) IN NORTHERN MONGOLIA
}

\author{
Buyanjargal B. ${ }^{\text {**, Tsydypzhap Z. Dorzhiev }{ }^{2} \text {, Roman Yu. Abasheev }}{ }^{I}$ \\ ${ }^{1}$ Laboratory of Entomology, Institute of General and Experimental Biology, MAS, Mongolia, \\ ${ }^{2}$ Department of zoology and ecology, Buryat State University, Russia \\ *corresponding author, e-mail: b_buyanjargal@outlook.com
}

\begin{abstract}
Flight phenology of forty-one vespid species were determined in northern Mongolia, using published data and our own samples. The studied species were divided into four phenological groups (summer species, late-summer species, summer-early autumn species and multi-seasonal species) depending on overlapping periods of the flight. Generally, flight phenology of vespid wasps in northern Mongolia is characterized as short lasting (50-150 days) between early May and late September, and mainly related with local environmental conditions and biology of particular species. Probability of occurrence of each species in particular time of the year was high ( $r$-value $\sim 1)$. The time of the year coincided for all studied species in a same period of time: from end of June to early August. Running title: Vespidae in northern Mongolia.
\end{abstract}

Keywords: light phenology; Mongolia; social and solitary wasps; Vespidae;

\section{INTRODUCTION}

The vespid wasp family Vespidae from the order Hymenoptera, is rich in species diversity and wide in distribution. The family contains more than 4200 species belonging to 6 subfamilies, representing different level of social organizations. Three subfamilies (Eumeninae with 3000 species; Polistinae, 800 species; Vespinae, 60 species) constitute more than $90 \%$ of total species and are widely distributed around the world. The other three subfamilies (Euparagiinae, 9 species; Stenogastrinae, 50 species; Masarinae, 250 species) have relatively restricted distributions in subtropical and tropical regions (Carpenter 1991).

Despite of the great diversity and wide distribution, the family is poorly studied in Central Asia, including Mongolia. There are
101 species of vespid wasps that have been recorded in Mongolia, which belong to 26 genera and 4 subfamilies (Buyanjargal 2016; Fateryga 2017). Besides faunal investigation, there are often needed biological and ecological studies on particular species or community for understanding of life history strategies of vespid species. In temperate region, as well as in boreal region like Mongolia, insect activity occurs only in a limited period of the year when physical environment are most favorable for development and reproduction (i.e. growing season). According to Wolda (1988), the phenology of adult flight refers the temporal distribution of the flight. Flight phenology of temperate vespid wasps are well studied specially in Europe for social (Archer 1990; Edwards \& Telfer 2001; Pawlikowski 
\& Pawlikowski 2009; Nadolski 2013), and solitary species (Haeseler 1978; Fateryga 2009).

Purpose of the present study is to provide

\section{MATERIAL AND METHODS}

A total of 2775 sampling date records of 41 vespid species in Mongolia were used. From these, 721 record data were extracted from the previous studies (Birula 1924; Kostylev 1937, 1940 a, b; Giordani Soika 1970, 1976; Kurzenko 1977; Eck 1984; Gusenleitner 1991; Dubatolov et al. 2002; Dvorak \& Castro 2007; Castro \& Dvorak 2009, 2010), but the other 2054 records were our sampling date records, which were collected during the period of 2011 to 2015. These sampling records were used to evaluate general pattern of flight phenology. Each month was divided into three 10-day periods, referred to as decades, to further characterize the onset and termination of flight. For example, flight begin on 06 June, would be recorded as the Decade I of June (refer to Appendix 1).

Moreover, the sampling dates were used as a circular data, in other words, days of a year may represent circular scales of measurement,

\section{RESULTS}

Flight phenology of 41 vespid species in northern Mongolia were determined by first summarizing the adult flight activity for every decade of the month using the combined data set (Appendix 1). Depending on overlapping general pattern of flight phenology of the northern Mongolian vespid species. and to determine their phenological characteristics.

where a year is divided into 365 equal intervals, called day, but where the designation of January 1st as the zero or starting point is arbitrary. One day of a year corresponds to $0.98^{\circ}$ of a circle (i.e., $360 / 365$ ), and $1^{\circ}$ of a circle corresponds to 1.01 days of a year. The days measured on a circular scale were converted to angular directions. Dispersion in the angular data, measured by r-value (Zar 1999), used for determining of general tendency of wasp flight periods. The r-value has no units and it may vary from 0 to 1 . Values close to 0 indicate that the probability of occurrence is the same in any unit of time of the year and values close to 1 indicate that all species occur in the same period of the year. The r-value calculated only on the temporal data of 2015, in which same sampling technique and intervals were used. Previously described circular analysis was done using NCSS11 Software.

periods of the flight, all species were divided into four phenological groups: summer species, late-summer species, summer-early autumn species and multi-seasonal species (Table 1).

Table 1. Flight phenological groups of vespid wasps

\begin{tabular}{|c|c|l|}
\hline $\begin{array}{c}\text { Flight phenological groups } \\
\text { (species number) }\end{array}$ & Period of flight & \multicolumn{1}{|c|}{ Species } \\
\hline & & $\begin{array}{l}\text { Ancistrocerus ichneumonideus, } \\
\text { A. nigricornis, A. oviventris, A. rufopictus, A. } \\
\text { hangaicus, Euodynerus notatus, Eu. dantici, } \\
\text { Stenodynerus punctifrons, St. clypeopictus, St. } \\
\text { pullus, Eumenes affinissimus, Onychopterochei- } \\
\text { lus turovi, On. eckloni }\end{array}$ \\
\hline
\end{tabular}




\begin{tabular}{|r|l|l|}
\hline Late-summer species (6) & July - September & $\begin{array}{l}\text { A. antilope, A. parietum, A. mongolicus, Sym- } \\
\text { morphus angustatus, S. lucens, Allodynerus } \\
\text { mandschuricus }\end{array}$ \\
\hline $\begin{array}{r}\text { Summer - early autumn spe- } \\
\text { cies (8) }\end{array}$ & June - September & $\begin{array}{l}\text { E. mongolicus, E. punctatus, Pseudepipona } \\
\text { herrichii, A. trifasciatus, Odynerus alpinus, } \\
\text { S. crassicornis, St. orenburgensis, Katamenes } \\
\text { tauricus }\end{array}$ \\
\hline Multi-seasonal species (14) & May - September \\
\hline & $\begin{array}{l}\text { E. coarctatus, E. septentrionalis, } \\
\text { E. tripunctatus, A. scoticus, } \\
\text { A. parietinus, Pterocheilus sibiricus, Vespula } \\
\text { germanica, V. vulgaris, V. rufa, Dolichovespula } \\
\text { saxonica, D.norwegica, D. sylvestris, Polistes } \\
\text { nimpha, } \\
\text { P. riparius, }\end{array}$ \\
\hline & \\
\hline
\end{tabular}

Flight periods of summer species began in I, II or III decade of June. However, flight onsets of male and female wasps of the same species are often differed. For instance, the males of Ancistrocerus rufopictus flew 10 days before the females, whereas the females of $A$. oviventris flew 20 days before the male. The ending periods of the adult wasps in this group occurred in August.

Late-summer species group includes only six species that have a very short flight period, i.e. 50-70 days, which were started in the beginning of July and terminated around the end of August or beginning of September, except for the females of $A$. parietum that flew until middle of September. The male individuals of these species began to fly 10-20 days before the females, except for Symmorphus lucens, which exhibited similar flight period for both sexes.

Eight solitary species of summer-early autumn species are generally appeared in the second decade of June, and their flight continued to early or middle of September. Therefore, the total duration of their flight ranged from 80 (Symmorphus crassicornis) to 110 days (Eumenes mongolicus). The flight onsets of both sexes of these two species were almost in the same period of time, but ending periods were differed.

The multi-seasonal species group includes eight social and six solitary species. Main feature of the species is prolonged flight duration (110-150 days) from May to lateSeptember. Generally, the worker individuals of social wasps emerged 25-30 days after the females appeared (Appendix I).

In addition to the seasonal flight period differences, the four groups differed from each other with adult flight duration $(\mathrm{F}=16.3, \mathrm{p}<$ 0.0001) (Fig.1).

The r-value for flight period of each species, which were captured in 2015, is shown in Table 2. All species have high probability to fly in constant period of time during growing season $(\mathrm{r} \sim 1)$ (Table 2). 


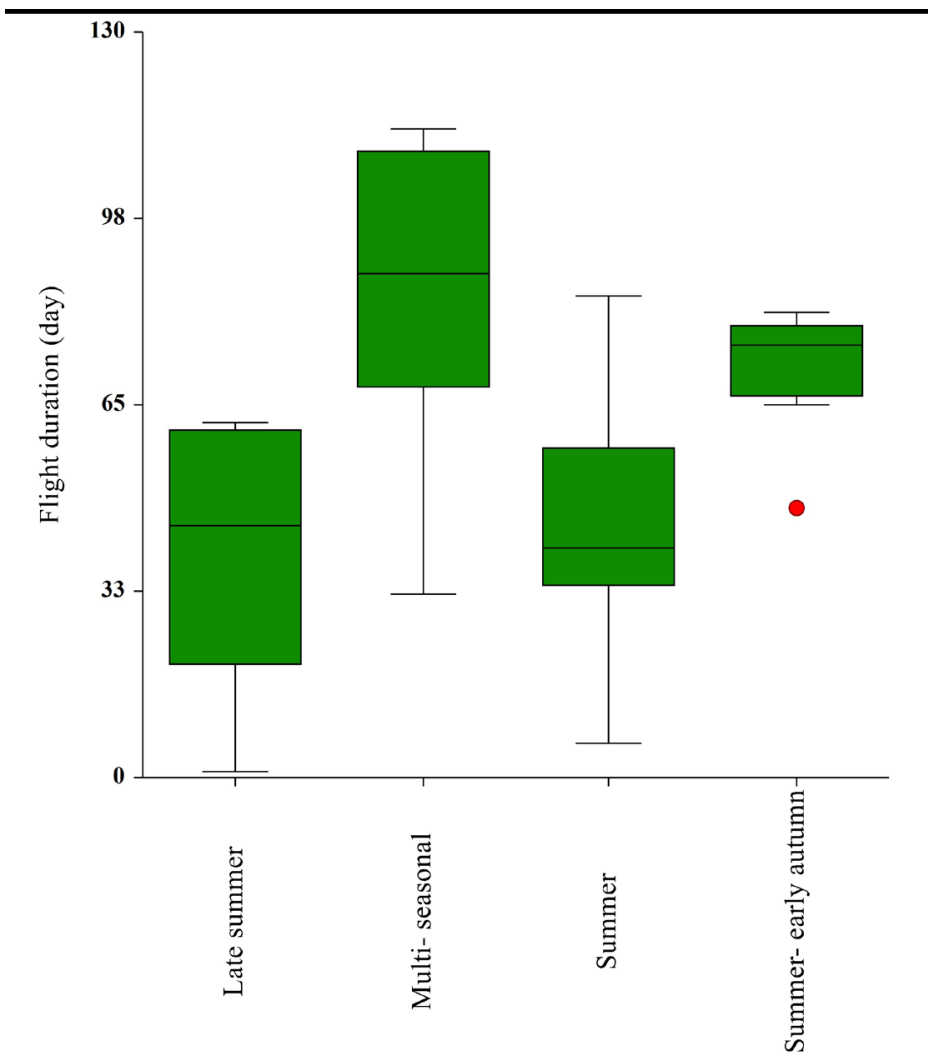

Figure 1. Flight duration of vespid wasp in different phenological groups

Table 2. Measure of dispersion (r-value) in flight periods for vespid species in 2015

\begin{tabular}{|l|c|c|c|c|c|}
\hline \multicolumn{1}{|c|}{ Species } & Sample size (n) & r-value & \multicolumn{1}{c|}{ Species } & $\begin{array}{c}\text { Sample } \\
\text { size n }\end{array}$ & r-value \\
\hline Allodynerus. sp. & 2 & 0.98 & Eu. quadrifasciatus & 1 & 1.00 \\
\hline Al. mandschuricus & 2 & 0.92 & K. tauricus & 4 & 0.99 \\
\hline A. hangaicus & 1 & 1.00 & O. alpinus & 1 & 1.00 \\
\hline A. ichneumonideus & 3 & 0.97 & On. eckloni & 9 & 1.00 \\
\hline A. oviventris & 1 & 1.00 & On. turovi & 1 & 1.00 \\
\hline A. parietinus & 5 & 0.99 & P. nimpha & 131 & 0.96 \\
\hline A. parietum & 1 & 1.00 & P. riparius & 240 & 0.95 \\
\hline A. rufopictus & 1 & 1.00 & Ps. herrichii & 53 & 0.96 \\
\hline A. scoticus & 5 & 0.90 & Pt. sibiricus & 1 & 1.00 \\
\hline A. trifasciatus & 6 & 0.94 & St. clypeopictus & 1 & 1.00 \\
\hline D. sylvestris & 14 & 1.00 & St. orenburgensis & 18 & 0.91 \\
\hline D. saxonica & 3 & 0.98 & St. pullus & 9 & 1.00 \\
\hline E. coarctatus & 7 & 0.90 & St. punctifrons & 5 & 0.99 \\
\hline
\end{tabular}




\begin{tabular}{|l|c|c|l|c|r|}
\hline E. mongolicus & 2 & 0.99 & S. angustatus & 1 & 1.00 \\
\hline E. punctatus & 25 & 1.00 & S. fuscipes & 10 & 0.97 \\
\hline Eu. dantici & 14 & 1.00 & S. lucens & 14 & 0.97 \\
\hline Eu. notatus & 17 & 1.00 & V. germanica & 1 & 1.00 \\
\hline
\end{tabular}

The flight period can be expressed using the mean direction of flight periods, which is calculated from converted angular data of raw recording dates for each species (Fig. 2).

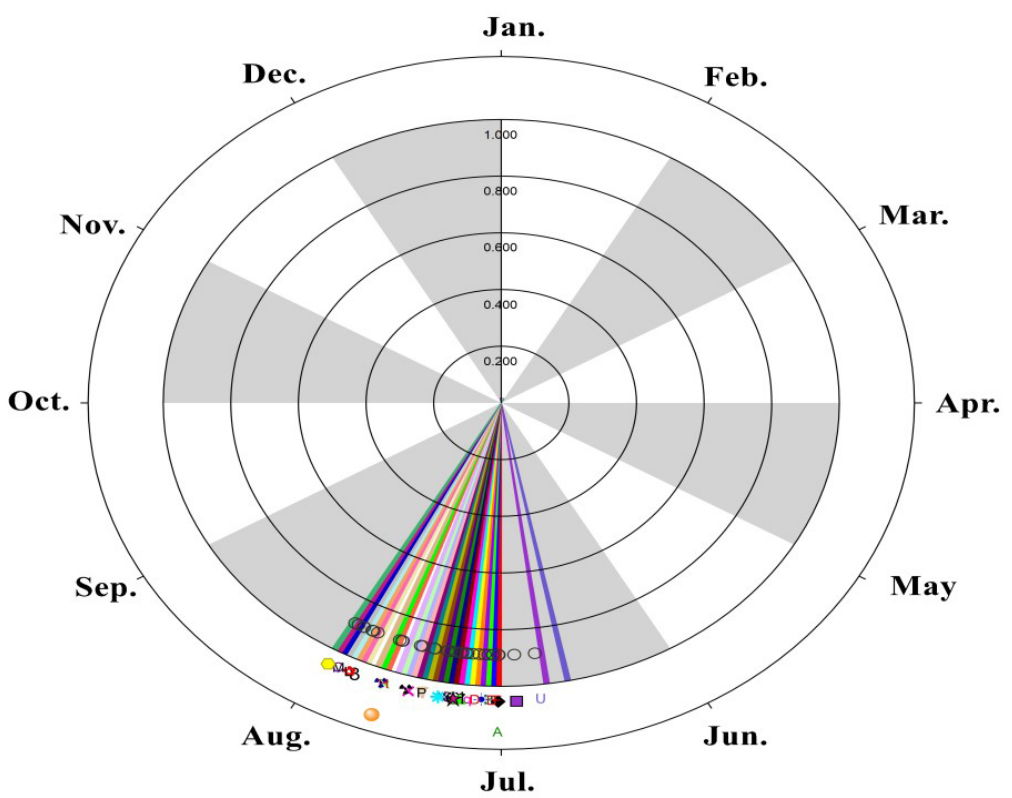
$\mathrm{H}$ A. hangaicus
$\because$ Allodynerus sp.
K. tauricus
S. angustatus
A. ichneumonideus S D. sylvestris
A. oviventris
C E. coarctatus
A. parietinus
M E. mongolicus
O. alpinus
S. fuscipes
- A. parietum
$P$ E. punctatus
On. eckloni
S. lucens
A. rufopictus
D Eu. dantici
u On. turovi
St. clypeopictus
A. scoticus
N Eu. notatus
$\therefore$ P. nimpha
St. orenburgensis
$R$ P. riparius
St. pullus
$\times$ A. trifasciatus
$\checkmark$ Ps. herrichii $\star$ St. punctifrons
q Eu. quadrifasciatus $\square$ Pt. sibiricus $\because$ V. germanica

* Al. mandschuricus

Figure 2. Circular diagram for flight activity of vespid wasps in northern Mongolia in 2015 (with the first day of each month shown)

From the mean direction of the recorded periods, the most diverse vespid wasp flight occurs in the middle of June to early August. In other words, all 34 vespid species in northern Mongolia, which were recorded in the growing season of 2015, can be active in the same period of time (Fig. 2).
However, from the range of the flight periods (Appendix I), the first flight of the wasps recorded in early May for $\mathrm{V}$. germanica, but in the late September, only few species namely V. germanica, P. nimpha, V. vulgaris, E. mongolicus remained as active. 


\section{DISCUSSION AND CONCLUSIONS}

Flight phenology of vespid wasps in northern Mongolia is characterized as short lasting between early-May to late-September, and primarily related with biology of particular species and local environmental conditions. The first yearly flight and flight duration of each species is influenced by the life history stage that overwinters (Scott \& Epstein 1987). Social vespid wasp species overwinter as an adult stage; whereas, solitary species overwinter as the last instar of larva. Flight activity of female social wasps began in May shortly after the weather conditions became favorable. However, during that period, the solitary wasp species undergoes development of larval and pupae stages, the duration of which also differed by species, before emerging as adults. Consequently emergence of adult solitary species and onset of their flights are occur later than in social wasps. Moreover, the longest flight period (120-150 days) was observed for the social wasps, such as V. germanica and P. nimpha, a result of earlier emergences and longer lifespan. However, the flight duration of these species are much shorter than those in European populations (200-250 days; Edwards 1980; Fateryga 2009; Rusina 2011).

Flight activity of each species is also influenced by biological features defined by local environmental conditions, such as temperature and humidity, especially in spring and autumn. Generally, insect phenology largely depends on local environmental

\section{Acknowledgements}

We would like to express our appreciations to Mr. James David Hamilton, Principal Advisor Biodiversity, HSES Department of Oyu Tolgoi LLC for his valuable and constructive recommendations that greatly improved the manuscript. We would also like to thank to Dr. Gantigmaa Chuluunbaatar, conditions (Reeve 1991; Forrest \& Thomson 2011). In Mongolia, local environmental conditions are often influenced by topology (Jambaajamts 1989). Moreover, Mongolia is characterized by an extremely continental climate with high ranges of diurnal and annual air temperatures and deficiency of precipitation. In other words, Mongolian vespid wasp populations inhabit ecosystems with extreme and highly variable weather conditions with diverse topology.

These climatic conditions result in a very short average vegetation growth period of 90 to 120 days (Yunatov 1977). This short vegetation period, possibly, reflects on the insect flight phenology and number of generation per year. The vespid species of Mongolia are possibly univoltine (one colony cycle per year) for social wasps. In addition, seasonal variation of resource availability, such as feeding plant flowering or provisioning prey activity often plays an important role in insect phenology, and their activity should be synchronized with the resources for survivorship (Wcislo 1987; Forrest \& Thomson 2011).

It is very important to understand inhabitation and adaptation of the species in the highly extreme environment, like in Mongolia. To gain greater insights into the Mongolian vespid wasps, further studies should consider assessing population dynamics of the vespid species through the flight periods and determining number of generations per year.

Laboratory of Entomology, Institute of General and Experimental Biology, MAS for her worthy discussions during the study and to Dr. Khaulanbek Akhmadi, Desertification Research Center, Institute of Geography and Geoecology, MAS for allowing the opportunity to perform the study. 


\section{REFERENCES}

1. Archer, M.E.1990. Seasonal flight activity of social vespinae (Hym., Vespidae) as monitored by Malaise trap catches. Entomologist's monthly magazine 126: 179-183.

2. Carpenter, J.M. Phylogenetic relationships and origin of social behavior in the Vespidae. pp. 7-29. In: Ross KG, Matthews RW (eds.) The social biology of wasps, Cornell University Press, Ithica, New York, 1991.

3. Dubatolov, V., Streltzov, A., Malikova, E. 2002. New data on distribution of social wasps (Hymenoptera, Vespidae: Polistenae, Vespinae) in the Asian Russia and North China. Animal World of the Far East 4: 117-122.

4. Eck, R. 1984. Vespinae (Insecta: Hymenoptera) aus der Mongolei (Ergebnisse der Mongolisch-Deutschen Biologischen Expeditionen seit 1962, Nr. 125). Erforsch. biol. Ress. MVR, Halie (Saale) 4: 71-73.

5. Edwards, R. Social wasps: Their biology and control. Rentokil Ltd, East Grinstead,1980.

6. Edwards, R., Telfer, M. Provisional atlas of the aculeate Hymenoptera of Britain and Ireland Part 3. pp 44-60. Biological records centre, Huntingdon, 2001.

7. Fateryga, A. 2009. Flight phenology of vespoid wasps (Hymenoptera: Vespidae) in the Crimea. The Kharkov entomological society gazette 16(1-2): 57-63.

8. Fateryga, A. 2017. New records of solitary vespid wasps (Hymenoptera: Vespidae: Eumeninae, Masarinae) from Russia and adjacent countries. Far Eastern Entomologists 334: 1-16.

9. Forrest, J., Thomson, J. 2011. An examination of synchrony between insect emergence and flowering in Rocky Mountain meadows. Ecological Monographs 81(3): 469-491.

10. Giordani-Soikan, A. 1970. Ergebnisse der zoologischen Forschungen von Dr. Z. Kaszab in der Mongolie. 223. Vespidae und Eumenidae (Hymenoptera). Annales historicnaturales musei nationalis hungarica 62: 325-333.

11. Giordani-Soika, A. 1976. Vespidi ed Eumenidi (Hymenoptera) raccolti in Mongolia dal Dr. Z. Kaszab. Acta zoologica Academiae scientiarum hungaricae 22(3-4): 271-276.

12. Gusenleitner, J. 1991. Vespoidea (Hymenoptera) aus der Mongolei und der sovietuniun. Linzer biol. Beitr., 23(2): 631-641.

13. Haeseler, V. 1978 Flugzeit. Blütenbesuch. Verbreitung und HZufigkeit Faltenwespen irn Norddeutschen Xefland (BRD)- (Vespoidea: Eurnenidae). Schr.Naturw. Ver. Schlew.Holst 48: 63-131.

14. Jambaajamts, B. 1989. Climate of Mongolia. The Institute of Geography, Mongolian Academy of Sciences, Ulaanbaatar, Mongolia.

15. Kostylev, G.1940a. Especes nouvelles et peu connues de Vespides, d'Eumenides et de Masarides palearctiques (Hymenoptera). Bull. Soc. Nat. Moscou. S. Biol., 49(3-4): 137154.

16. Kostylev, G. 1940b. Especes nouvelles et peu connues de Vespides, d'Eumenides et de Masarides palearctiques (Hymenoptera). Bull. Soc. Nat. Moscou S. Biol., 49(4-5): 2442.

17. Kurzenko, N.1977. Solitary vespid wasps (Hymenoptera, Eumenidae) of the Mongolian People's Republic and adjacent territories of China and South Siberia. Insect of Mongolia 5: 537-582.

18. Morawitz, F. 1889. 201. Morawitz, F. Insecta, cl. G. N. Potanin in China et in Mongolia novissime lecta. IV. Hymenoptera aculeate. Hor. Soc. ent. Ross., 23: 112-168.

19. Nadolski, J. 2013. Phenology of European Hornet, Vespa crabro L. and Saxon Wasps, Dolichovespula saxonica. Sociobiology 60(4): 477-483.

20. Pawlikowski, T., Pawlikowski, K. 2009. Phenology of social wasps (Hymenoptera, Vespidae) in the Kujawy region (Northen Poland) under the influence of climatic changes 1981-2000. Bulletin of Geography- physical geography series, 1: 125-134. 
21. Reeve, H. Polistes. In: Kenneth G, Matthews R (eds) The Social Biology of Wasps. pp. 99-148. Comstock Publishing Associates, Ithaca, New York, 1991.

22. Rusina, L. 2011. Host Discrimination by Elasmus schmitti (Hymenoptera, Eulophidae) and Latibulus argiolus (Hymenoptera, Ichneumonidae), Parasitoids of Colonies of Polistes Wasps (Hymenoptera, Vespidae). Entomological Review 91(9): 1081-1087.

23. Scott, J., Epstein, M.E. 1987. Factors affecting phenology in a temperate insect community. The American Midland Naturalist 117(1): 103-118.

24. Wcislo, W. 1987. The roles of seasonality, host synchrony, and behaviour in the evolutions and distributions of nest parasites in Hymenoptera (Insecta). With special reference to bees (Apoidea). Biol. Rev.,62: 515-543.

25. Wolda, H. 1988. Insect seasonality: Why?. Annual review of ecology and systematics 19:1-18.

26. Yunatov, A.A. Fundamental Characteristics of the Vegetation of the Mongolian People's Republic. pp 52-53. State publisher, Ulaanbaatar, 1977.

27. Zar, J. Biostatistical analysis. 5th ed. pp 605-621. Pearson prentice hall, Upper Saddle River, New Jersey, 1999. 

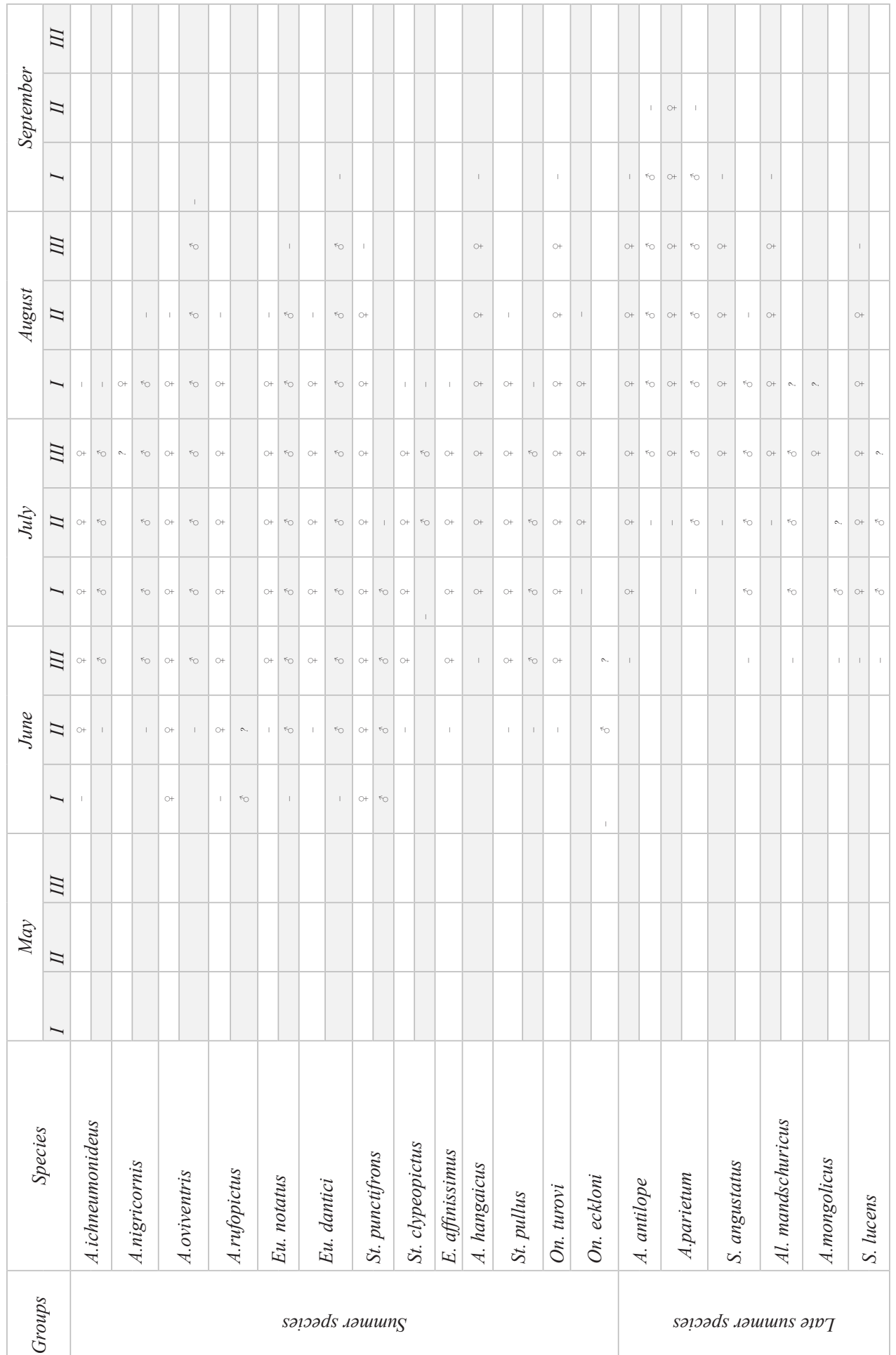
Proceedings of the Mongolian Academy of Sciences $\quad$ Vol. 57 No 04 (224) 2017

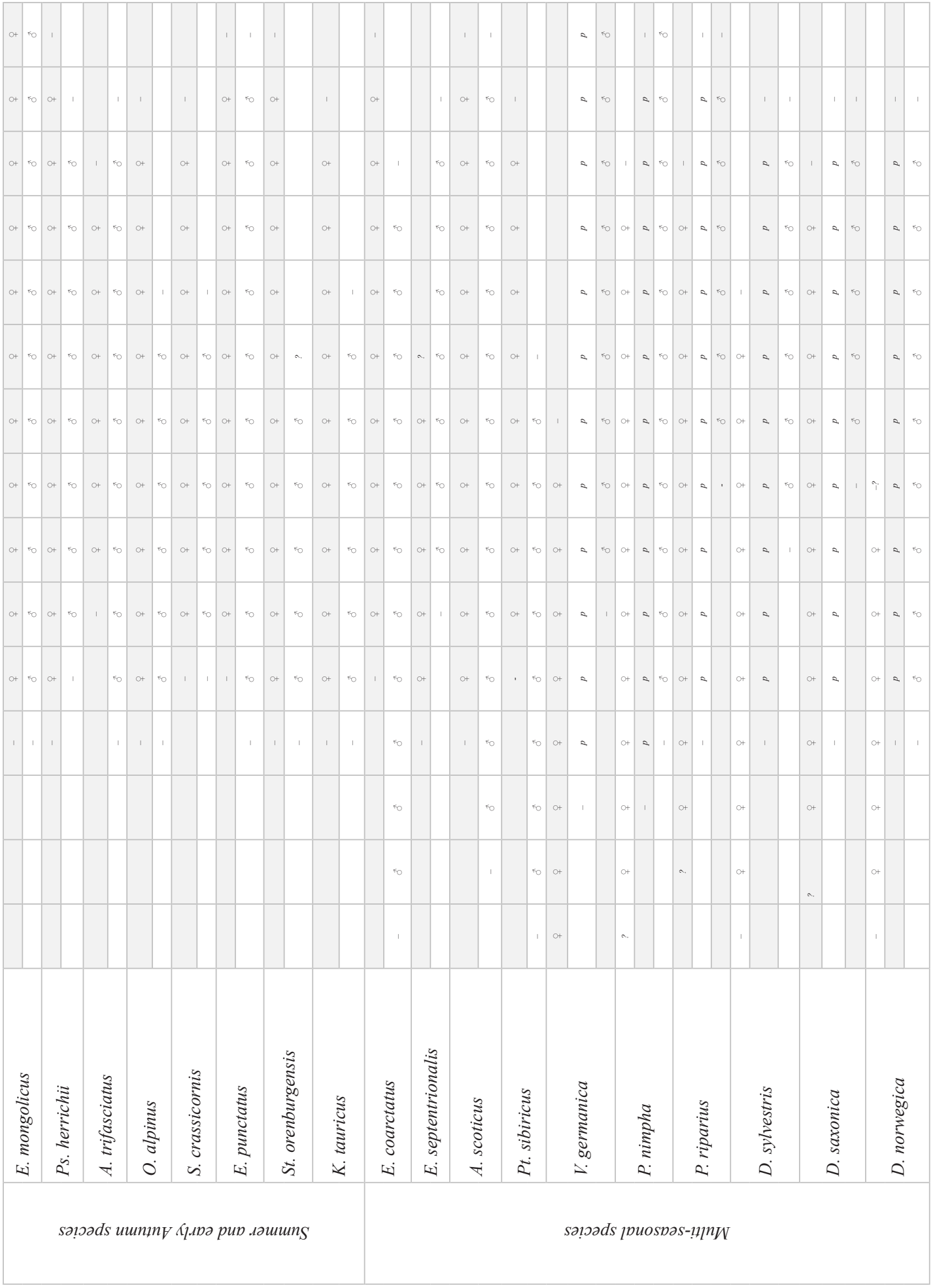




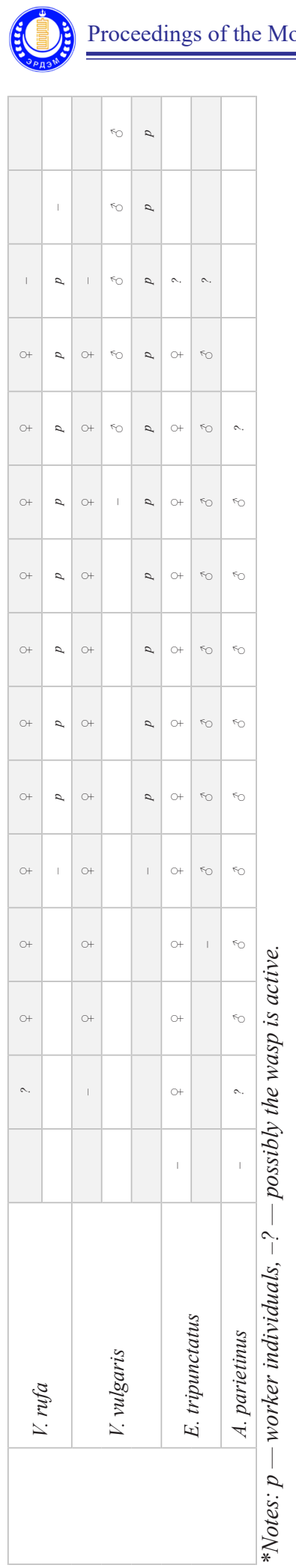

